\title{
Study of Three Residential Complexes in the City of Vienna
}

\section{Rozbor tři obytných souborů ve městě Vídeň}

Jana Matyášová, xasotnatova@stud.fa.vutbr.cz

Ústav urbanismu, Fakulta architektury, Vysoké učení technické v Brně školitel: doc. Ing. arch. Gabriel Kopáčik, Dr.

\begin{abstract}
This study belows to project GA ČR reg. č. 17-26104S supervised by doc. Kopáčik. It covers three residential complexes built in one district of the city of Vienna. The mentioned complexes are Frauen Werk Stadt, Compact City a Car - free housing.
\end{abstract}

KEYWORDS: Floridsdorf; residential complex; compact city; car-free housing; inhabitants' satisfaction; community

\begin{abstract}
ABSTRAKT: Tato studie se v rámci výzkumného úkolu projektu GA ČR reg. č. 1726104 S pod vedením doc. Kopáčika zabývá třemi obytnými soubory postavenými v jedné čtvrti města Vídeň. Jedná se o bytové soubory Frauen-Werk-Stadt, Compact City a Autofreie Mustersiedlung (Car-Free Housing) nacházející se ve čtvrti Floridsdorf. Jsou to obytné soubory, které vznikaly v rámci třech odlišných filozofií a prŕístupů. Jsou postaveny blízko sebe, se stejnou dostupností a s podobnými podmínkami, proto je můžeme vzájemně porovnávat.
\end{abstract}

KLÍČOVÁ SLOVA: Floridsdorf; obytný soubor; kompaktní město; bezautové bydlení; spokojenost obyvatel; komunita 


\section{Úvod}

Tato studie porovnávající tři obytné soubory ve městě Vídeň je první součástímé disertační práce. Její téma „proměny obytných území" v sobě zahrnuje výzkum vybraných obytných souborů z Brna a z Vídně. Cílem disertační práce je pochopit vztah mezi společenskými, ekonomickými a politickými podmínkami a uspořádáním domů v obytných souborech (urbanistickou strukturou). Práce má za cíl srovnat jednotlivé typy souborů vzniklých v odlišných myšlenkových a filozofických směrech. Tato studie porovnává tři soubory, které budou zahrnuty ve výčtu obytných souborů v rámci celé disertační práce.

Cílem této studie je srovnat zmíněné obytné soubory z hlediska měřitelných urbanistických kritérií, popsat základní myšlenky jejich návrhů, srovnat dostupná statistická data o obyvatelích a data $\mathrm{z}$ místního šetření. Na základě těchto informací lze určit, do jaké míry jsou spokojenost obyvatel a jejich chování v obytných souborech ovlivněny strukturou souboru či myšlenkami, v rámci kterých byl daný soubor navržen.

\section{Širší souvislosti}

Obytné soubory zkoumané v této studii se nacházejí ve Vídni, ve čtvrti Floridsdorf. Počet obyvatel Vídně se pohybuje kolem 1,76 milionu (2014), přičemž k největšímu nárůstu obyvatel docházelo na začátku 20. století. Samotná čtvrt’ Floridsdorf má 150 tisíc obyvatel (Lebhart, 2016).

Město Vídeň je inovativní a podporuje myšlenky šetrnosti vůči životnímu prostředí a to, aby bylo i takovéto bydlení dostupné všem vrstvám společnosti. Tento koncept sociální a environmentálně udržitelné bytové politiky se postupně vyvíjí. Podle uváděných statistik město Vídeň každoročně investuje do cca pěti až sedmi tisíc nových bytů, což je asi 80-90 \% všech nově dokončovaných bytů. (Förster, 2008)

Floridsdorf je vídeňský 21 . městský obvod, nachází se v severní části města, na sever od řeky Dunaj. Všechny tři vybrané obytné soubory přiléhají k ulici Donaufelder Straße. Na situaci je patrný obytný soubor č. 1 (OS1) - Frauen-Werk-Stadt, obytný soubor č. 2 (OS2) - Car-Free Housing a obytný soubor č. 3 (OS3) - Compact City.

Floridsdorfje napojen na městskou hromadnou dopravu linkou metra U-Bahn U6 (konečná stanice v blízkosti obytného souboru Car-Free Housing), vlakem S-Bahn (stanice Wien Brünner Straße, nádraží Wien Siemensstraße) a tramvajovými a autobusovými linkami.

V okolí sledovaných obytných souborů se nachází drobná zahrádkářská kolonie, kostel, park, sportovní areál (Donaufeld) a rameno řeky Dunaj (Alte Donau) využívané k rekre- 
aci. Obytné soubory se nachází na pomezí tradičnějši struktury blokové zástavby a drobné zemědělské oblasti, se kterou se počíá při budoucím vývoji čtvrti jako s místem rozvoje.

\section{Obytný soubor 1: Frauen-Werk-Stadt}

Prvním zkoumaným obytným souborem je Frauen-Werk-Stadt, postavený v letech 1995-1997 na kř́ižení ulic Donaufelder Straße a Carminweg. Autorkami projektu jsou Liselotte Peretti, Gisela Podreka, Elsa Prochazka a Franziska Ullmann.

Obytný soubor vznikl díky „Frauenbüro“ - ženskému odboru města Vídeň a byl do detailů promyšlen, aby vyhovoval každodenním potřebám žen.

Bytový komplex obsahuje 360 bytů, školku, integrované byty pro ženy s pohybovým omezením, komunikační centrum, šest integrovaných bytů pro starší osoby a obchodní jednotky podél Donaufelder Straße.

Jednotlivé budovy tvoří celek obepínající uzavřený dvůr, ve kterém bylo navrženo několik různorodých podob vnitrobloku, malých náměstí, zahrádek a hřišt doplněných o systém chodníků a zeleně. Důraz byl kladen na zajištění přirozeného osvětlení v každém bytě, na cirkulaci vzduchu a na různorodé výhledy. Okna kuchyní a obývacích pokojů jsou orientována do rozdílných směrů. (Förster, 2008)

Klíčovým prvkem celého návrhu bylo vytvoření různých obytných jednotek ve snaze vyhovět potřebám různých typů domácností. Např́iklad v části navrhované Elsou Prochazka, která má 85 bytů a školku, se architektka zaměřila na vytvoření bydlení pro všechny fáze života. Pokoje jsou navrženy s obecnou platností, aby se předešlo konkrétnímu určení jejich použití. (Sánchez de Madariaga, 2016)

Plocha parcely je 2,18 ha, přičemž rozloha zastavěného území je 0,99 ha. K ulici Donaufelder Straße přiléhá zvýšená, pětipodlažní část obytného souboru o výšce cca 17 $\mathrm{m}$, jinak je soubor převážně tvořen čtyřpodlažními budovami o výšce cca 15 metrů. Školka, která k souboru ze západní části přiléhá, je dvoupodlažní. Index zastavěné plochy (dále jen IZP) je 0,45 a index podlažní plochy (dále jen IPP) je 1,88.

Z místního šetření vyplynulo, že komunita v obytném souboru funguje, avšak nikoliv zásadně. Ve vnitrobloku si za hezkého počasí hrálo jen několik dětí a lidé se vzájemně spíše nezdravili. Pravděpodobně se potkávají a znají spíše méně.

\section{Obytný soubor 2: Car-Free housing}

Obytný soubor Autofreie Mustersiedlung, také nazývaný Car-Free Housing, byl 
postaven v letech 1996-1999, autory projektu jsou S\&S Architekten. Obytný soubor má 244 jedno- až pětipokojových bytů. Bylo rozhodnuto, že na jeden byt je požadován či povolen pouze jeden automobil, díky čemuž není potřeba tolik prostoru na parkovací plochy a obytný soubor je doplněn o komunitní místnosti či hrací dětské zóny. V souboru také funguje systém sdílení aut. K dalšímu snížení ekologické náročnosti používá budova solární a geotermální energii, sofistikovaný systém splachování a vysoký stupeň zateplení. (Förster, 2008)

Parcela projektu má 1,04 ha, rozloha zastavěného území je 0,43 ha. Budovy jsou šestiči sedmipodlažní, o výšce kolem $18 \mathrm{~m}$. Střechy jsou plně využity solárními panely, zahrádkami obyvatel a terasami. Obytný soubor je tvořen dvěma uzavřenějšími bloky. IZP je 0,41 a IPP 2,67.

K obytnému souboru byla vytvořena studie (viz tabulka na konci článku), která řeší otázku dopadu snížení počtu automobilů na obyvatele. $\mathrm{V}$ rámci této studie $\mathrm{z}$ roku 2004 bylo dotazováno všech 244 bytů, odpovědělo pouze 42 .

Z místního šetření, jež probíhalo ve stejnou denní dobu jako u obytných souborů 1 a 3, vyplynul silný pocit fungující komunity. Na dvorech si hrály děti, lidé se zdravili a povídali si. Bylo možné vidět obyvatele různých věkových kategorií sedící ve vnitroblocích.

\section{Obytný soubor 3: Compact City}

Compact City čili kompaktní město je urbanistický koncept, který při vyšší hustotě osídlení mísí více funkcí. Díky tomu pomáhá snižovat znečištění ovzduší a snižuje nutnost používání automobilů a každodenního ježdění daleko za prací či za nákupy. Napomáhá také větší společenské interakci a pocitové bezpečnosti v rámci jednotlivých komplexů budov. (Dempsey, 2010)

Koncept kompaktnosti měst se propsal do návrhu od architektů BUSarchitektur (ve spolupráci s C. Blazicem, R. Lalicsem a L. Spinadel), postaveném ve vídeňském Floridsdorfu v letech 1991-2000. Projekt byl v roce 1998 oceněn cenou Otto Wagner Urban Development Prize. Compact City je hybridní struktura velkého městského polyfunkčního bloku, do kterého jsou integrovány různé funkce a bydlení (54 bytů, 12 ateliérových bytů, 14 dílen, 22 kanceláří, 2 obchody, supermarket, banka, 3 restaurace, dětské centrum, hřiště, centrum pro mládež a 21 skladů).

Blok je rozdělen do dvou hlavních rovin. První je na úrovni městského parteru a druhá pak na stř̌ešní piazzetě s hřištěm, která je obklopena různými službami a provozovnami. Nosnou ideou projektu je existence skupiny lidí, které architekti nazývají 
„homeworkers“ - lidí bydlících a individuálně pracujících na stejném místě, mnohdy přímo v bytě. Jsou to vesměs různí řemeslníci, umělci, programátoři, drobní obchodníci či př́slušníci různých svobodných povolání. (Stavba, 2005)

Parcela o rozloze 0,91 ha je téměř celá zastavěná - zastavěné území pokrývá 0,72 ha. Celý komplex je postaven na dvoupodlažním základu, ze kterého vyrůstají další, menší budovy. Na severní stranu, směrem do přilehlého parku, jsou orientovány čtyři čtyřpodlažní objekty. K ulici přiléhá zvýšená, pětipodlažní část. Z ulice se také dá vyjet eskalátorem na plochu mezi budovami - zmíněnou piazzetu. Výšky budov se tedy liší, výška budov u ulice činí kolem 17 m, u parku 13,5 m a piazzeta má kolem $6 \mathrm{~m}$. Za průměr, jímž jsou myšleny nejčastější hodnoty, budeme tedy považovat čtyři podlaží o výšce $13,5 \mathrm{~m}$. IZP je 0,79 , IPP je 2,44.

Přesnější statistická data k tomuto souboru nejsou bohužel dostupná. Dosud nebylo provedeno dotazování obyvatel. Uvedu alespoň pro srovnání dostupná data z celého města Vídeň (ve srovnávací tabulce ve sloupci 4).

Z místního šetření bylo patrné, že ani zde, alespoň navenek, komunita nefunguje stejně jako v př́padě obytného souboru 1 př́liš výrazně. Je však nutné si uvědomit, že $\mathrm{v}$ prrípadě tohoto souboru se mezilidské vztahy nemusí odehrávat pouze ve vnitrobloku, nebot jakousi formou vnitrobloku a místem pro možné setkávání jsou budovy samotné, proto je nutné se při př́štím místním šetření pokusit proniknout hlouběji do vnitřku budovy.

\section{Porovnání vybraných obytných souborů}

Obecné informace:

$\begin{array}{llll} & 1 & 2 & 3 \\ \text { Rozloha celého souboru (ha) } & 2,18 & 1,05 & 0,91 \\ \text { Zastavěné území } & 0,99 & 0,43 & 0,73 \\ \text { Výška budov } & 15 & 18 & 13,5 \\ \text { Počet podlaží } & 4 & 6 & 4 \\ \text { Index zastavěné plochy } & 0,45 & 0,41 & 0,79 \\ \text { Index podlažní plochy } & 1,88 & 2,67 & 2,44 \\ \text { Počet bytů } & 360 & 244 & 66 \\ \text { Odhadovaný počet obyvatel } & 993,6 & 627,1 & --\end{array}$

Statistická data o obyvatelích:

Průměrný počet lidí

$\mathrm{v}$ domácnosti 
Průměrný počet dětí

v domácnosti

$$
0,91
$$

0,67

Průměrná velikost

bytu $\left(\mathrm{m}^{2}\right)$

82,6

86

Vzdělání obyvatel

střední škola (\%)

odborné učiliště (\%)

8,7

7,2

33,2

technické liceum (\%)

15,2

4,8

28,6

maturitní zkouška (\%)

10,9

4,8

10,6

vysokoškolské vzdělání (\%)

39,1

38,1

15,8

23,9

45,2

11,8

Zaměstnání

Kancelářské práce -

white collar workers (\%)

52,2

52,4

Dělníci - blue collar workers (\%) 2,5

8,7

Státní úředníci (\%)

6,5

14,3

13

OSVČ (\%)

4,3

2,4

5,7

$\mathrm{V}$ důchodu (\%)

6,5

11,9

28,8

$\mathrm{V}$ přípravě na povolání (\%)

8,7

7,1

8,5

Nezaměstnaní (\%)

4,3

4,8

5,6

Průměrný roční

čistý př́ijem (eur)

$30867 \quad 32282$

28320

*data pro obytný soubor 3 nejsou dostupná, v kolonce 4 se jedná se o průměrná data pro Vídeň (Data dostupná z Ornetzender, 2008)

Zajímavé jsou údaje z provedených dotazníků ve zmíněné studii dotazující se na společenské vztahy obyvatel. Bohužel jsou dostupná data pouze pro první dva obytné soubory, přičemž statistika ukazuje, že např. průměrný obyvatel obytného souboru Car-Free Housing by nazval 16 osob ze stejného souboru svými práteli, avšak u souboru Frauen-Werk-Stadt je to pouze 7 osob. V projektu Car-Free Housing se průměrný obyvatel také zná až se 101 osobami od vidění, u souboru Frauen-Werk-Stadt je to pouze 62. Dále u projektu Car-Free Housing odpovídalo kolem $85 \%$ dotazovaných kladně na otázky, zda mají dobré sousedy a zda si vzájemně pomáhají (FrauenWerk-Stadt pouze kolem 20 \% dotázaných). Dokazuje to, že sdílení jednotné myšlenky nezávislosti na autech může zvyšovat sociální soudržnost obyvatel, což potvrdila také místní šetření.

Pokud hledáme vztah mezi strukturou obytných souborů a obyvateli, tato studie může prokázat, že pokud se obyvatelé stěhují do obytného souboru v rámci nějaké myšlenky (u př́padu Car-Free Housing je to sdílení automobilů), o které jsou sami přesvědčeni, 
a proto se do souboru stěhují, má tento fakt na jejich chování větší vliv než samotná myšlenka projektu. Pokud je má myšlenka projektu ovlivnit spiše druhotně, je možné, že $\mathrm{v}$ takovém př́padě bude komunita $\mathrm{v}$ obytném souboru fungovat méně sounáležitě (jak je vidět na př́ikladu obytných souborů 1 a 3). Jeví se, že chování obyvatel více než uspořádání domů (urbanistická struktura) ovlivňuje jejich společná idea. Je však nutné tuto hypotézu ještě prošetřit.

Př́spěvek vznikl ve vazbě na výzkumný projekt GA ČR 17-26104S Vliv charakteru a umístění urbanistické struktury na udržitelný rozvoj území.

\section{Prameny}

DEMPSEY, Nikola, 2010. Revisiting the Compact City. Built Environment. 2010(36), 5-8. FÖRSTER, Wolfgang, Gabriele KAISER, Dietmar STEINER a Alexandra VIEHHAUSER, 2008. Housing in Vienna. Vídeň: Architekturzentrum Wien.

LEBHART, Gustav a Ina TAXACHER, 2016. Wien - Bezirke im Fokus: Statistiken und Kennzahlen. Vídeň: Magistrat der Stadt Wien, MA 23. Wien. ISBN 978-3-901945-23-6. ORNETZEDER, Michael, Edgar G. HERTWICH, Klaus HUBACEK, Katarina KORYTAROVA a Willi HAAS. The environmental effect of car-free housing: A case in Vienna. Ecological Economics [online]. Elsevier B.V, 2008, 65(3), 516-530. ISSN 0921-8009.

SÁNCHEZ DE MADARIAGA, Inés. a Marion. ROBERTS, 2016. Fair shared cities: the impact of gender planning in Europe. 2. Londýn: Routledge. 310-311. ISBN 978-1-40941024-9.

Stavba. Praha: Business Media CZ, 2005, č. 05. ISSN 1210-9568.

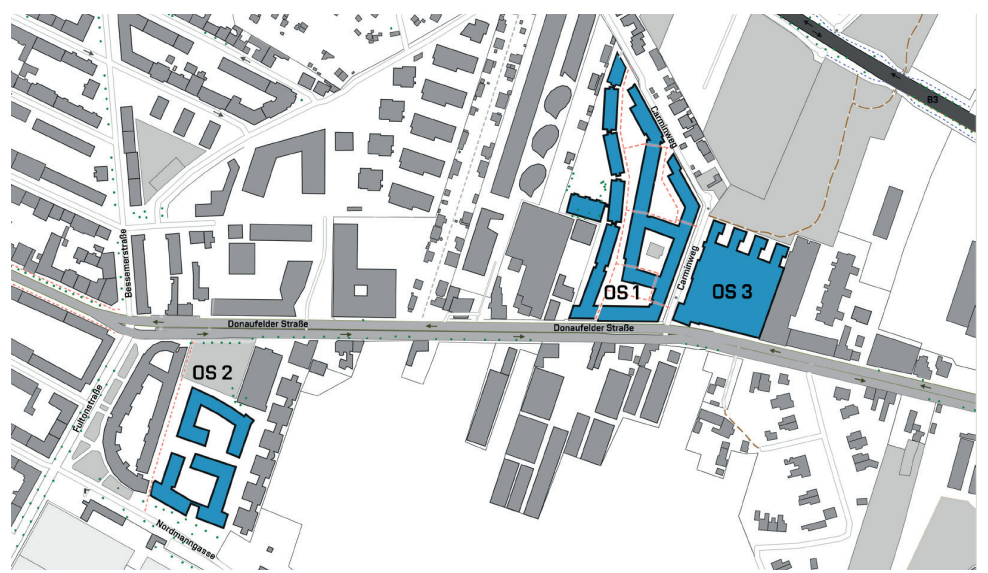

Obr. 1. Situace Donaufelder Straße (Zdroj: archiv autora) 